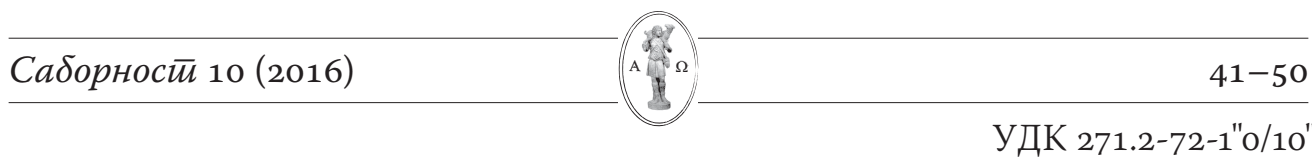

271.2-1

DOI: $10.5937 /$ sabornost10-12536

Оригинални научни рад

Ignatije Midić

University of Belgrade, Faculty of Orthodox Theology, Belgrade

\title{
Primacy within the Church
}

\section{Ecclesiological Presumptions and Church Practice in the First Millennium} (Orthodox Aspect)

\begin{abstract}
For the right understanding of primacy within the Church and of Church practice in relation to primacy before the Great Schism of 1054, it is necessary, to consider two problems: perception of the Church, and perception of Apostolic Succession-Tradition in Church history of the first millennium. The Synod deals with matters which insure Eucharistic unity in the form of Apostolic Tradition. However, Apostolic Tradition in all its aspects: in consecration of bishops, in teaching, and in its missionary activity, is always connected with the Eucharist with which it is being identified.
\end{abstract}

Key words: primacy, Church, Apostolic Succession-Tradition, Kingdom of god, Synod.

Eor the right understanding of primacy within the Church and of Church - practice in relation to primacy before the Great Schism of 1054, it is necessary, in my opinion, to consider two problems: perception of the Church, and perception of Apostolic Succession-Tradition in Church history of the first millennium.

1. Basing our knowledge on the testimony as presented to us by Apostle Paul in his epistles and the testimony of the later Church authors, we may conclude that the Church was regarded as identical to the Eucharistic communion presided by a bishop. The word "Church" as employed by Apostle Paul in his epistles signified the local Church, and not in any of her manifestations but as a gathering of all Christians living in one place for the purpose of celebrating the Holy Eucharist. This conclusion is based upon the text of 1 Cor. 11. In this chapter of the named epistle, as well as in those following it, Apostle Paul talks about Eucharistic gatherings of the Christians of Corinth which he identifies as the Church: "When you come together as a Church, I hear that there are divisions among you..." (1Cor. 11:18) When you gather as a Church you gather 
as a Eucharistic communion. Therefore, as far as Apostle Paul is concerned, gathering in one place with the purpose of celebrating Eucharist is the same as coming together as the Church.

At the same time the Eucharist also has its own concrete structure represented by the First, the presiding, the one leading the Eucharistic service and offering gifts of the Church to God the Father, together with the gathering of all the faithful around him. This structure, which is originally to be found in the Pauline 1 Cor. 14:16, was later on clearly defined by other Church authors as the bishop, who is the head of the Eucharistic communion and the one who is offering gifts of the Church to God the Father, surrounded by presbyters, deacons, and the people of God (see Ignatius of Antioch).

Identical notion of the Church was also implemented by the later Holy Fathers such as: St. Ignatius of Antioch, Maximus the Confessor, Athanasius of Sinai, St. Nicholas Cabasilas etc. And so, ancient Christians consciously identified the Church with a Eucharistic gathering.

Today this understanding has been adopted not only by Orthodox theologians, but by many Roman Catholics, as well as Protestants (Мидич, 2013). If there are any reservations or criticisms in relation to this theme, such as those dealing with an "exaggerated" identification of the Church with the Eucharist, or with a "one-sided" emphasis given to the Eucharist at the expense of other aspects of Church life, then they have come to pass because the so-called critics of the so-called "Eucharistic ecclesiology" understand Eucharist as one of the seven Sacraments. Their view was formed under the influence of Scholastic theology which has wrongly limited the Eucharist to one sacrament of the "seven", thus ignoring the ancient tradition which saw Eucharist as the recapitulation of the entire Mystery of Christ, and not only as one of its elements or aspects. Scholastic theology, and the analytical method which it employed in its approach to the mystery of salvation, managed to segment a single, unique, mystery of salvation into many independent elements, leaving each of these elements independent and in no relationship with each other: Christology, Pneumatology, Triadology, Eschatology, Ecclesiology, etc. The same happened with the Church, which had become an independent element in relation to the Sacraments in spite of the fact that the Sacraments make the Church real, i.e. they make it be. Thus, by this segmentation of the single, unique, Mystery of Christ, the Eucharist has become one of the seven Sacraments, independent in its relation to others: Baptism, Chrismation, etc. It might perhaps be better to say that other Sacraments have become independent in relation to the Eucharist. This is why identification of the Church with the Eucharist is absolutely unacceptable to those who approach the Mystery of the Church in this way. If we should attempt to rise above Scholasticism, which is very difficult to accomplish today, then we might see that all Sacraments are included in the Holy Eucharist, which is giving them their meaning and their ecclesial 
aspect, just as it is giving meaning and the ecclesial aspect to all other activities which are on the Church agenda.

On the other hand, the Eucharist, i.e. the Church, exists in the world, but it is not of the world. This conclusion concerning the Church is derived above all from the Holy Eucharist, and this is because the Eucharistic gathering is an icon of the Kingdom of God. At least it is seen as such by the Eastern tradition, while the Western understanding of the Eucharistic gathering sees it as an icon of something that has happened in the past. When St. Maximus the Confessor speaks of the Eucharist, i.e. of the Church, (see Mystagogy, PC 91, 688 and ff.) he sees in her an icon (protiposis) of future events, i.e. of the coming of the Kingdom of God. St. Maximus sees the Kingdom of God as an event of the future being revealed in history, and this is, as far as St. Maximus is concerned, why the entire holy history represents the foretaste, an icon, of the Age to come, which is the only truth. This is expressed by his words: "The Old Testament is the shadow, the New Testament is the icon, but the truth is in the Age to come". This Kingdom of God which is to come is especially and somehow most realistically being revealed by the Holy Eucharist.

What are ecclesiological consequences of this identification of the Eucharist and the Church?

The Holy Eucharist expresses, and reveals, and incarnates the Church, i.e. it makes her real in history. The Eucharist makes the Church local with very clear limits without bringing into question her wholeness, i.e. the Church in her fullness, the catholicity of the Church. When Apostle Paul speaks of the Eucharistic gathering in one place, he calls this gathering the Church in full (oli Ecclesia). St. Ignatius speaks of the Eucharistic gathering in one place under one bishop when he calls it the Catholic Church (see Ign. Smyr., 6, 8), as do other Church authors. This is because catholicity, i.e. fullness, is not seen by Eastern Fathers as a quantitative, or as a geographical notion, but as a qualitative one. The very structure of the Eucharist - bishop surrounded by presbyters, deacons, and the people of God, as well as the activities within, denotes the structure of the Kingdom of God and that which is to come to pass within. Thus One, Holy, Catholic, and Apostolic Church, i.e. "the Church of God" (Ec-

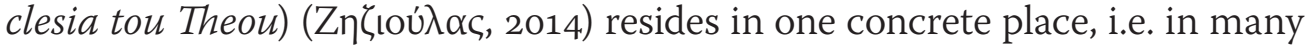
places, as the Eucharist, without ceasing to be the Church of God in its fullness.

The Eucharist manifests the Church of God in history, and not only such as it is today, but also such as it is going to be when the Kingdom of God is upon us. This is why the Eucharist is an icon of the coming Kingdom of God and not of the past events. Since in the coming Kingdom of God all nations shall gather in one place around Jesus Christ, the Son of God, who will sit in judgment of the world surrounded by apostles and all that are holy, the Eucharist is above all a gathering of all the faithful belonging to one place; within this Eucharistic gathering, bishop is the icon of Christ, presbyters are icons of 
apostles, and the people of God are icons of the holy. The very structure of the Eucharist, deriving from the coming Kingdom of God, as well as its orientation towards the future, give the Eucharist the character of the Church in full. It is on the basis of the Eucharist that the Church is the communion not of this world, although residing in the world. Her relationship with the world is such that the Church receives in her bosom the world, such as it is, so as to make it immortal, i.e. to transfigure it into the Kingdom of God. At the same time, the Eucharist is the means, the paradigm, of how the Church should live and how it should be founded in history. In other words, the Eucharist is the true nature of the Church upon which the Church identity is being founded; this identity is guarding the Church from being identified with the world through a multitude of her other activities during her historical existence (Мидић, 2015).

It is from this understanding of the Church that the understanding of the Apostolic Tradition of the Church in the East is based upon.

2. When at the beginning of $2^{\text {nd }}$ century the Church found itself under the pressure of Gnosticism which claimed to hold the true learning of the Apostles, it was forced to lay emphasis on its true Apostolic Tradition and introduce the criteria which, from then on, became the basis for any verification of Church authenticity. Which criteria did the Church introduce as the only parameters of Church authenticity, i.e. authenticity of Apostolic Tradition? History of this problem, i.e. available sources relative to Apostolic Tradition, allows us to reach various conclusions on this matter.

Dominant present day position in the East concerning Apostolic Tradition says that Apostolic Tradition is being passed on through consecration ( $h i$ erotonia) of bishops. This is testified by St. Hippolytus in his work Apostolic Tradition, which is a liturgical text dealing with consecration of bishops and presbyters. What is this tradition all about?

Hippolytus' text allows us to conclude that it is through consecration of bishops that the true faith is being preserved such as it was in apostolic times. However, this faith should not be understood in a sense of it being simply a learning. Hippolytus himself directs us towards this conclusion by saying that the Church is not a school, i.e. one of many philosophical schools of the period, where the learning is being passed on from teacher to student thus making it the "tradition of learning". By his consecration the bishop is, above all, being placed as the head of a Eucharistic communion whose duty is to offer gifts of the Church to God the Father, thus making Apostolic Tradition a Eucharistic ministry which is being passed on as the Eucharist, which is also an expression of the true faith. This is also testified by the practice of the Church of the East which has been preserved to this day, it being that bishops are consecrated during the celebration of the Eucharist primarily to celebrate the Eucharist, although this doesn't exclude their gift of teaching and their care for the 
preservation of true faith which is expressed through the gift of preaching (both of which they are also being entrusted with through consecration).

Thus, in the context of Apostolic Tradition, it should be emphasized that any given bishop does not succeed apostles through his consecration, as it is thought in the West which had been influenced on this matter by the interpretation of St. Cyprian of Carthage. He especially does not succeed such apostles by whose authority he might claim certain positions in the Church, as it was being thought and written about in the West in relation to the bishop of Rome as the successor of Apostle Peter on the throne of bishops of Rome; through his consecration, each bishop succeeds Christ as the head of the Church.

Ecclesiological repercussions of this understanding of Apostolic Tradition in the East are following: a bishop being consecrated within the context of a Eucharistic gathering so that he might celebrate the Eucharist becomes the head of the Eucharist, i.e. of the Church, and an icon of Christ (alter Christus). By receiving the gift to teach and to "bind and loose", he, simultaneously, also becomes the successor of the apostles (alter apostolus). However, since the consecration of a presbyter, of which we are also being informed in Hippolytus' text, entails passing on of the gift of teaching, which is above all to be connected with apostles, the presbyters primarily become icons of apostles.

On the other hand, each consecration of a bishop in the Church of the East also signifies constitution of the Church, i.e. of the Eucharist. This is why each consecration of a bishop is also a celebration of Pentecost, which is emphasized by the Eucharist being celebrated at the occasion of a bishop's consecration. Thus, Apostolic Tradition signifies constitution of the Eucharist as the Church. This constitution, however, does not signify a transfer of the Church from the past into the present, but it signifies a manifestation in history of the coming Kingdom of God as the Eucharist; and this because the Eucharist is attended by Christ as the bishop, by apostles as presbyters, and by all that are holy as the people of God. Once again this indicates that each Eucharistic communion under one bishop is the Church in full - the Catholic Church of God.

3. Emergence of the ministry of the "First" in the Church, or the so called "Primate", is simultaneous to the emergence of the institution of the Synod within the Church. However much it seems that the institution of the Synod has nothing to do with the essence of the Church, the following pages of this modest referral will attempt to demonstrate the very opposite. Institution of the Synod, as understood by the Church of the East, is based upon the notion of the Church as a Eucharistic communion, and it represents its very essence. Because, if each local Church, being a bishopric and a Eucharistic communion, is the Church in full, then her very existence requires a state of unity with other Churches. This state of unity is secured by the bishop through the Synod, or Assembly, or Council of bishops. Furthermore, it is necessary to establish unity of many bishoprics (dioceses) on the plane of the universal (ecumenical) 
Church. It is for this reason that the institution of Synods has emerged in Church history. Let us briefly take a glance at the history of the emergence of Synods, at their structure, and at the role Synods have within the life of the Church and her true existence.

The roots of the Synod as an institution, as testified by some of the most ancient sources of the New Testament - epistles of St. Paul, are to be found in the very structure of the Church as a Eucharistic communion. In his 1 Cor. 5 Apostle Paul speaks of a "Sinod" consisting of the president of the Eucharist, presbyter, which is held in the presence of the people, i.e. during Eucharist, and which judges whether or not a member of the local Church of Corinth should be allowed to partake in the Eucharist. It is of the same sort of a Synod, which will have a decisive effect on the formation, structure, and authority of later Synods (regional and ecumenical), that St. Ignatius speaks of. He speaks of the "bishop's synod" (sinedrion episkopu) (Filad. 8, 1; Magn. 6, 1). Bishop's synod consists of the bishop, presbyters, and the people of God which at the occasion of a Eucharistic gathering discuss and pass judgment on matters relative to the unity and one-mindedness of the Church before the Holy Communion.

Thus, Synod as an institution emerged in the earliest phases of Church history so as to secure the unity of the local Church as a precondition for the Holy Communion. As such, it is of concern to the very essence of the Church if we should accept the fact that without unity of its members, i.e. Eucharistic unity, there can be no Church. This unity of the Church on the local plain is secured by the bishop who is the presiding member both of the Eucharistic gathering and of the bishop's synod.

a) Emergence of the Metropolitan Synod: Institution of the Synod as emerging in its $2^{\text {nd }}$ century form is concerned with the same problem, i.e. maintenance of Eucharistic unity, and this is most obviously revealed by the $5^{\text {th }}$ canon of the First Ecumenical Council. Careful study of this canon, which represents the very first clear testimony of the institution of the Synod in the Church on the permanent basis, shows that the institution of the Synod is most closely related to the problem of partaking in the Holy Eucharist. This canon speaks of those who have been excluded from the Eucharist (excommunicated) and says the following: "Concerning those, whether of the clergy or the laity, who have been excommunicated, the sentence is to be respected by the bishops of each province according to the canon which forbids those expelled by some to be admitted by others. But let an inquiry be held to ascertain whether anyone has been expelled from the community because of pettiness or quarrelsomeness or any such ill nature on the part of the bishop. Accordingly, in order that there may be proper opportunity for inquiry into the matter, it is agreed that it would be well for synods to be held each year in each province twice a year, so that these inquiries may be conducted by all the bishops of the province assembled together, and in this way by general consent those who have offended 
against their own bishop may be recognized by all to be reasonably excommunicated, until all the bishops in common may decide to pronounce a more lenient sentence on these persons. The synods shall be held at the following times: one before Lent, so that, all pettiness being set aside, the gift offered to God may be unblemished; the second after the season of autumn".

Based on this canon we might conclude the following: 1. that Metropolitan Synods were institutions in which participation and decision making was limited to bishops of one region. This is because bishops were heads of Churches and guarantors of Church unity, and it was in their persons that Synods were in fact synods of Church communions, and not of individual persons; 2. that the Synod was dealing with problems relative to the unity of a local Church as a Eucharistic communion; 3. and what is of particular importance to the subject we are dealing with, that it is the duty of the Synod to maintain balance between the local Church (as the Church in full without destroying her integrity) and the Catholic Church which is formed by the unity of local Churches in one body. Maintenance of this balance was not at all easy throughout history; especially so if we take into consideration the fundamental principle of the ancient Church that none of the bishops should interfere within the jurisdiction of another diocese, because as St. Cyprian says: "if the bond of unity exists and the mystery of the catholic Church continues to be indivisible, then each bishop should arrange his actions and his jurisdiction in such a way he feels is right, and for this he is to be accountable only to God" (Cyp. Ep. 55 (52), 21). How did the Synod maintain the fullness of the local Church while, at the same time, insuring the unity of the Church on the ecumenical (universal) plane?

The quoted canon points out to us that the decision of a local Church concerning exclusion from the Eucharist should be respected by all local Churches. It is in this way that the fullness of the local Church is being preserved. At the same time this canon gives us the right also to conclude that the Synod has the right to interfere within the jurisdiction of the local Church, but only in relation to a matter concerning Church unity, i.e. to conclude whether or not bishop's decision to excommunicate somebody was taken for "personal reasons". What does this mean? This obviously means that the Eucharist is the connection between one local Church and other Churches, and that it serves as the element of their unity on the universal plane. In other words, the Holy Eucharist simultaneously expresses both the catholicity and fullness of the local Church, and the catholicity of the Church on the universal plane. Because, exclusion of somebody from Eucharist by one Church automatically implies his/her exclusion by the rest of the remaining Churches. The very nature of the Eucharistic gathering is such that it requires existence of a Synod as a ne-

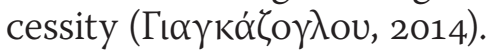

In addition to the quoted canon which is directing us towards the necessity of existence of the institution of the Synod in the Church as a means of 
preservation of her fullness, i.e. of her true existence both on the local and on the ecumenical level, we should also mention the $34^{\text {th }}$ Apostolic canon which deals with the problem of Synodical structure and the question of Primacy in the Church.

This canon determines that: 1 . in each region (ethnos) there should be a "first" among bishops who should be recognized as the "head"; 2. each bishop of the region should handle that which is not in his competence, i.e. all common matters, only in agreement with the "first"; and 3. the "first" should do nothing without the agreement of all.

This canon insures that the institution of the Synod, whose main function is (as we have already seen) to preserve the catholicity of the local and the universal Church, can not be envisaged without a First being in it. A Synod can not exist on the local, regional, or universal level without a "first" being in it. However, the First in the Synod, who is being recognized as such by other bishops, can do nothing without obtaining agreement from other bishops. Relationship of the First with the rest of the bishops in the Synod is the relationship of mutual dependency, i.e. interdependency. The First can do nothing without other bishops, and the others can not do anything without the First. Of course, this has to do only with such matters which are of common concern, and most of all with the matter of Eucharistic unity. This interdependency between the First and other bishops points towards true unity within the Church which we have in the Holy Trinity as pointed out by the concluding words of this canon: "For thus there will be concord, and God will be glorified through the Lord in the Holy Spirit, Father, Son and Holy Spirit".

The role of the First in the Synod is to convene the Synod and to secure the balance with local Churches, safeguarding their fullness and the fullness of the Synod. Synod is not an institution towering above the local Church and, being such, it administers the Church as a collective body. Synod is a gathering of local Churches in their fullness and in persons of bishops; decisions in the Synod are taken in full agreement of all bishops, and the chief parameter of all such decisions is Apostolic Tradition which is none other than the Eucharistic communion of the local Church. Therefore, Synodical decisions need to be passed through the Eucharistic communion of each local Church. At the same time, Synod has authority in relation to the local Church only in matters concerning Eucharistic unity.

Primacy of the Bishop of Rome at the occasion of Ecumenical Councils is manifested as a consequence of the structure of Metropolitan Synods. Bishop of Rome did not receive primacy in the Church because of the fact that he is the successor of Apostle Peter on the throne of bishops of Rome through Apostolic Succession. He received his primacy owing to the Metropolitan system of Synods. In this context it was logical that, among metropolitans who were the first among bishops in their respective regions, bishop of the grand imperial 
city of Rome should assume the first place among bishops on the universal level, and at the occasion of Ecumenical Councils.

\section{Conclusion}

Institution of the Synod, based upon the learning and practice of the Church in its first millennium, and safeguarded by the Church of the East, stems from the very nature of the Church which is to be identified as the Eucharistic communion. Synodical structure is equal to the structure of the Eucharistic communion. Eucharistic communion can not exist without its First, without the bishop, just as the institution of the Synod can not exist without the First in the Synod. The First in both cases can do nothing without unity with all others, just as others can do nothing without unity with the First. The role of the First both in the Eucharistic gathering and in the Synod is to secure the unity of many without bringing to question fullness and integrity of each individual, i.e. of each local Church. The Synod deals with matters which insure Eucharistic unity in the form of Apostolic Tradition. However, Apostolic Tradition in all its aspects: in consecration of bishops, in teaching, and in its missionary activity, is always connected with the Eucharist with which it is being identified.

\section{Литература}

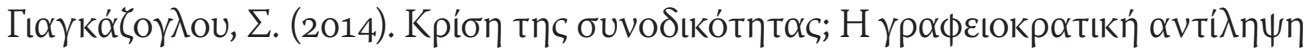

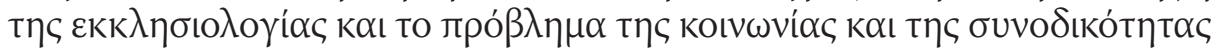

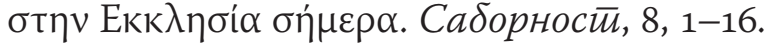

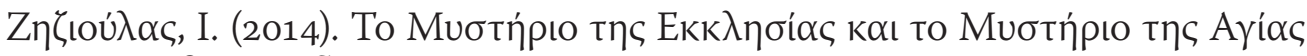

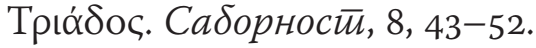

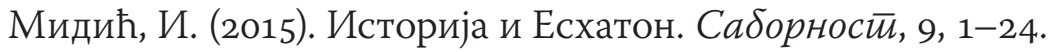

Мидич, И. (2013). Православное богословие сегодня - Проблемы и пер-

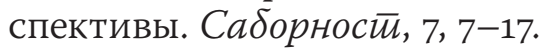


50

\author{
Игнатије Мидић \\ Универзитет у Београду, Православни богословски факултет, Београд

\section{Примат у Цркви} \\ Еклисиолошке претпоставке и црквена пракса у првом миленијуму \\ (православни приступ)
}

а правилно разумевање примата у Цркви и црквене праксе у односу
два период пре Великог раскола 1054. године, неопходно је размотрити
ком првог миленијума историје Цркве. Примат и синодалност уско су по-
везани и тичу се очувања евхаристијског јединства. Апостолско предање,
пак, у свим својим аспектима (епископске хиротоније, поучавање, мисија)
увек је до идентификације повезано са Евхаристијом.

Key words: Примат, Црква, апостолско предање, Царство Божје, Синод, саборност.

Датум пријема чланка: 5. 9. 2016.

Датум прихватања чланка за објављивање: 1. 12. 2016. 